Gut, 1971, 12, 291-296

\title{
Immunoglobulin-containing cells in the coeliac syndrome
}

\author{
K. W. PETtingale \\ From the Department of Medicine, King's College Hospital Medical School, London
}

SUMMARY Immunofluorescent studies were performed upon the small intestinal mucosa obtained by jejunal biopsy of seven patients suffering from the coeliac syndrome and six control subjects. Seven patients had normal villous morphology and six had subtotal villous strophy. In the group whose jejunal biopsies were normal using routine histological examination, the predominant type of immunoglobulin-containing cell was IgA followed by $\operatorname{IgM}$, then $\operatorname{IgG}$, with the approximate ratio of 3:2:1 respectively. The cell densities were found to be much higher than in other published series and the predominance of IgA was not so marked. These findings may be in part due to differences in technique, but probably are also due to differences in the patients studied. In the group with villous atrophy the density of $\operatorname{IgA}$ cells was significantly lower than in the group with normal histology and three of the six patients showed a reversal in the normal ratio between IgA- and IgM-containing cells. A positive correlation was observed between serum IgM levels and the density of corresponding immunoglobulin-containing cells.

The predominance of IgA in various exocrine secretions has been well established (Gugler and Van Muralt, 1959; Hanson, 1960; Tomasi and Zigelbaum, 1963; Josephson and Lockwood, 1964; Masson, Heremans, and Prignot, 1965; Tomasi, 1968), and although its exact role in the production of local immunity has not been defined it is clear that it can function as an isohaemagglutinin and possess antibacterial and virusneutralizing properties (Adinolfi, Glynn, Lindsay, and Milne, 1966; Tokumaro, 1966). There is also evidence that exocrine IgA is produced locally rather than by selective transport from the serum, as immunofluorescent studies on the salivary gland and the gastrointestinal tract have shown in normal subjects a similar predominance of IgA-containing plasma cells (Tomasi, Tan, Solomon, and Prendergast, 1965; Crabbé, Carbonara, and Heremans, 1965).

Isolated deficiency of $\operatorname{IgA}$ has an incidence of about 1 in 500 (Bachmann, 1965; Hobbs, 1968), and the majority of patients have had symptoms which are probably attributable to this immunoglobulin deficiency (Hobbs, 1968). These symptoms have included diarrhoea (West, Hong, and Holland, 1962; Claman, Hartley, and Merrill, 1966; Hobbs, 1968) and malabsorption with villous atrophy (Crabbé and Heremans, 1967). Subsequent immunohistochemical studies to assess the possible role of IgA Received for publication 17 December 1970. deficiency in the pathogenesis of coeliac disease have produced conflicting results. IgA-containing cells have been shown to be predominant by some workers (Rubin, Fauci, Sleisenger, and Jefferies, 1965; Eidelman, Starkey, Lagunoff, and Rubin, 1966) but others have shown an excess of IgMcontaining cells (Søltoft, 1970; Douglas, Crabbé, and Hobbs, 1970).

This paper presents a further immunofluorescent study on the small bowel mucosa of patients with coeliac disease.

\section{Subjects}

Seven patients with the coeliac syndrome were studied together with six control patients undergoing investigation for various gastrointestinal symptoms. It was not thought justifiable to perform jejunal biopsy on subjects for whom there was no clinical indication.

The histological appearances of the jejunal mucosa in six of the coeliac group were of subtotal villous atrophy and the remaining patient had a normal biopsy. The appearances of all the control biopsies were normal. Six of the coeliac group had been untreated, and the remaining patient with a normal biopsy originally had subtotal villous atrophy and for 10 years since had received a gluten-free diet (Table I). 


\begin{tabular}{|c|c|c|c|c|c|}
\hline Patient & Sex & $\begin{array}{l}\text { Age } \\
(y r)\end{array}$ & Clinical Details & $\begin{array}{l}\text { Jejunal } \\
\text { Biopsy }\end{array}$ & $\begin{array}{l}\text { Length of } \\
\text { Treatment }\end{array}$ \\
\hline $\begin{array}{l}\text { M.S. } \\
\text { A.L. } \\
\text { J.O. } \\
\text { M.W. } \\
\text { M.H. } \\
\text { L.L. } \\
\text { A.P. } \\
\text { D.J. } \\
\text { G.R. } \\
\text { R.B. }\end{array}$ & $\begin{array}{l}\mathbf{F} \\
\mathbf{F} \\
\mathbf{M} \\
\mathbf{M} \\
\mathbf{F} \\
\mathbf{M} \\
\mathbf{M} \\
\mathbf{F} \\
\mathbf{M} \\
\mathbf{F}\end{array}$ & $\begin{array}{l}70 \\
58 \\
54 \\
57 \\
52 \\
72 \\
32 \\
60 \\
19 \\
45\end{array}$ & $\begin{array}{l}\text { Coeliac syndrome } \\
\text { Coeliac syndrome } \\
\text { Coeliac syndrome } \\
\text { Coeliac syndrome } \\
\text { Coeliac syndrome } \\
\text { Coeliac syndrome } \\
\text { Coeliac syndrome } \\
\text { Osteomalacia } \\
\text { Crohn's disease } \\
\text { Unexplained }\end{array}$ & $\begin{array}{l}\text { Normal } \\
\text { SVA } \\
\text { SVA } \\
\text { SVA } \\
\text { SVA } \\
\text { SVA } \\
\text { SVA } \\
\text { Normal } \\
\text { Normal } \\
\text { Normal }\end{array}$ & $\begin{array}{l}10 \text { years } \\
\text { None } \\
\text { None } \\
\text { None } \\
\text { None } \\
\text { None } \\
\text { None } \\
\text { None } \\
\text { None } \\
\text { None }\end{array}$ \\
\hline R.D. & $\mathbf{M}$ & 35 & $\begin{array}{l}\text { Zollinger-Ellison } \\
\text { syndrome }\end{array}$ & Normal & None \\
\hline $\begin{array}{l}\text { G.N. } \\
\text { P.S. }\end{array}$ & $\begin{array}{l}\mathbf{M} \\
\mathbf{M}\end{array}$ & $\begin{array}{l}65 \\
30\end{array}$ & $\begin{array}{l}\text { Partial gastrectomy } \\
\text { Ulcerative colitis }\end{array}$ & $\begin{array}{l}\text { Normal } \\
\text { Normal }\end{array}$ & $\begin{array}{l}\text { None } \\
\text { None }\end{array}$ \\
\hline
\end{tabular}

Table 1 Details of patients studied

\section{Tissue Specimens}

Jejunal biopsies were obtained from the proximal jejunum with a Watson suction intestinal biopsy capsule and the biopsy specimen was divided into two parts. The first part was examined under a dissecting microscope and then placed in $10 \%$ formol saline for routine histology. The second part was frozen immediately in liquid nitrogen and stored wrapped in polythene bags at $-20^{\circ} \mathrm{C}$ until use. Twelve to 20 serial sections 3 to $5 \mu$ thick were prepared using a Bright's cryostat at a temperature of $-20^{\circ} \mathrm{C}$ and affixed to a microscope slide.

\section{Immunofluorescent Methods}

\section{ANTISERA}

Specific antisera prepared in rabbits to human IgA, IgG, and IgM and conjugated with fluorescein isothiocyanate were obtained from Behringwerke (Hoechst Pharmaceuticals Ltd). Non-conjugated rabbit antihuman IgA, IgG, and IgM and conjugated goat antirabbit whole gamma globulin were also obtained. These antisera had been fractionated to separate the gamma globulin fractions absorbed with charcoal and tissue homogenates and shown to be monospecific to their corresponding antigens before and after conjugation by the manufacturers.

\section{FLUORESCENT STAINING}

The sections of jejunal mucosa were stained with the fluorescent antisera using the direct and the indirect technique (Nairn, 1964). Each section was fixed for 15 minutes in $95 \%$ ethyl alcohol at $37^{\circ} \mathrm{C}$, and the slides were washed in two successive baths of phosphate-buffered saline $p \mathrm{H} 7 \cdot 1$ for 10 minutes. Excess buffered saline was removed from the slide with blotting tissue.
For the direct technique two drops of fluorescent antihuman IgA, IgG, and IgM were placed on each slide and the slides left in a moist chamber at room temperature for $\mathbf{3 0}$ minutes. Excess antiserum was then removed with successive baths of buffered saline for 10 minutes and the sections mounted in an aqueous mountant for microscopy.

Specificity of the staining by each conjugate was confirmed by the 'blocking' technique (Nairn, 1964). Unconjugated antihuman IgA, IgG, and IgM were placed on the slides and these were left at room temperature in a moist chamber for 30 minutes. After washing in buffered saline the appropriate conjugated antihuman antisera were added for 15 to 30 minutes. Specific fluorescent staining was inhibited by this technique.

In the indirect or 'sandwich' technique, two drops of unconjugated rabbit antihuman IgA, IgG, and IgM were placed on the sections and these placed in a moist chamber for $\mathbf{3 0}$ minutes at room temperature. Excess antiserum was removed by placing the sections in two successive baths of buffered saline for 10 minutes. Two drops of conjugated goat antirabbit gamma globulin was added to each slide for a further $\mathbf{3 0}$ minutes at room temperature. The slides were finally washed in buffer and mounted as before.

Control sections were incubated with conjugated goat antirabbit gamma globulin alone and no fluorescent staining was observed. Sections were also stained with haematoxylin and eosin for identification of cell morphology.

\section{FLUORESCENT MICROSCOPY}

The stained sections were examined with a Gillett and Sibert fluorescence conference microscope using an iodine quartz light source and a blue primary filter 35/033, with a heat-absorbing filter 30/001. The microscope was equipped with a Gillett and Sibert Autolynx camera with an automatic exposure meter. For examining the fluorescent areas a immersion dark ground condenser was used with a $\times 55$ fluorite oil immersion objective and a $\times 8$ eyepiece. Secondary filter combinations were chosen to give apple green specific fluorescence on a red background.

Quantitative measurements of the fluorescent and non-fluorescent areas were obtained using a modified method of Crabbé et al (1965). Colour photographs of three high-power fields on each section were obtained using Kodak Ektochrome daylight colour reversal film. These were projected onto a sheet of graph paper at standard $\times 5$ magnification, and the outline of fluorescent and nonfluorescent areas in the lamina propria were drawn in by hand. The areas thus delineated were then measured from the squares on the graph paper and 
converted to cubic millimetres by superimposing a photograph of a micrometer slide. The error in the reproducibility of drawing the fluorescent areas was within $3 \%$.

The average size of the fluorescent mononuclear cells was estimated by obtaining a measurement of 30 well individualized cells, and the density of cells per cubic millimetre was calculated from the mean cell volume and the ratio of the volume of fluorescent cells to the total volume of lamina propria in the field. The density of cells (d) was derived from the equation

$$
\mathrm{d}=\frac{\mathrm{Vf} \times 1}{\mathrm{Vi} \mathrm{Vc}} \text { where } \mathrm{Vf} \text { and } \mathrm{Vi} \text { are the }
$$

volumes of the fluorescent cells and the total volume of the lamina propria respectively. Vc is the mean cell volume. The ratio $\mathrm{Vf} / \mathrm{Vi}$ was calculated from the corresponding cross-sectional areas of the specifically fluorescent cells and total area of lamina propria and the ratio of the areas converted to volumes by the formula

$$
\left(\frac{\mathrm{Af}}{\mathrm{Ai}}\right)^{3 / 2}=\frac{\mathrm{Vf}}{\mathrm{Vi}}
$$

The mean cell volumes were derived from the mean cell radius, on the assumption that the cells are spherical.

\section{SERUM IMMUNOGLOBULIN LEVELS}

Serum IgG, IgA, and IgM levels were measured by the single radial diffusion method (Mancini, Vaerman, Carbonara, and Heremans, 1964; Fahey and McKelvey, 1965) using commercially available immunoplates (Hyland Laboratories). The coefficient of variation for duplicate samples was $\pm 3.5 \%$ for $\mathrm{IgG}$, $\pm 2.5 \%$ for $\operatorname{IgA}$, and $\pm 6 \%$ for IgM.

\section{Results}

Specific fluorescent staining was not satisfactorily obtained using the direct fluorescent technique, and the interpretation of sections was made more difficult by the very bright autofluorescence of eosinophils which were particularly numerous in patients with villous atrophy.

Indirect fluorescent staining produced excellent specific fluorescence of large numbers of cells in the lamina propria and the autofluorescent eosinophils were much more easily distinguished. This technique was consequently used throughout.

The fluorescence of the lamina propria usually contrasted with the dark background of the columnar epithelium of the crypts and villi, although occasionally there was some non-specific fluorescence of the
Controls with Normal Jejunal Histology

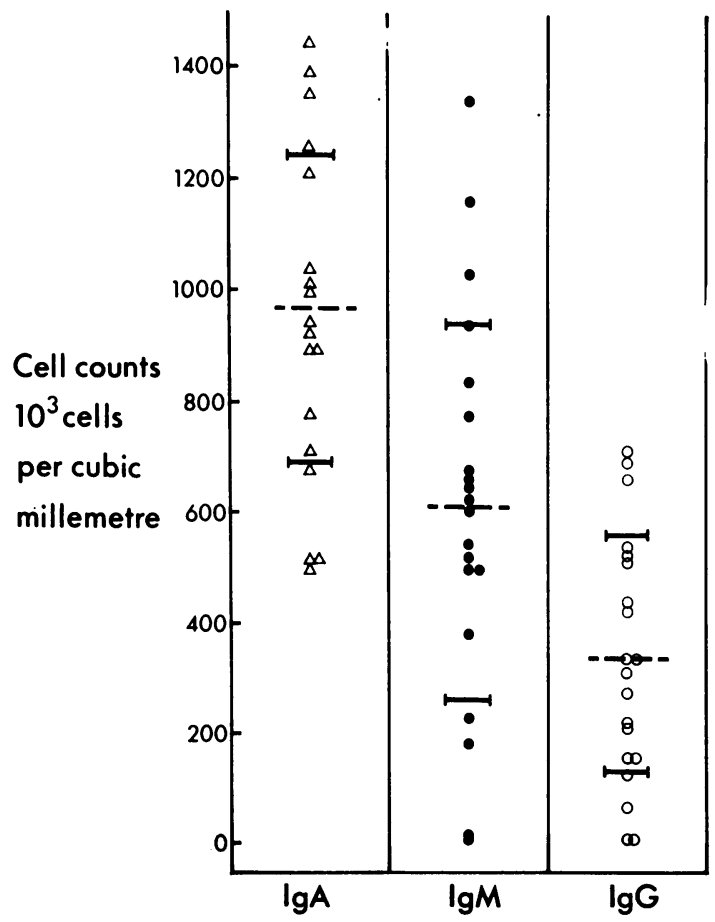

Fig. 1 Distribution of cell counts in controls with normal jejunal histology. Differences between mean densities were all significant.

epithelial cells, and some non-specific staining of the mucus in goblet cells was seen with all the antisera. Fluorescent cells were so abundant that cell contours could not be recognized and quantitation of fluorescence by direct cell counts was not possible; thus the more indirect method of quantitation was used.

In the sections from the group with normal jejunal histology the fluorescence obtained with IgA antisera appeared to be more abundant than fluorescence obtained by either IgM or IgG but the distribution of fluorescence in the lamina propria was the same. The amount of fluorescence in different parts of a given section varied considerably, and there appeared to be less fluorescence at the tips than at the bases of the villi.

The population densities calculated on 20 fields for each of the three classes of immunoglobulincontaining cells in the group with normal histology are shown in Figure 1. There was a wide variation of cell densities between fields of the same immunoglobulin class, and considerable overlap between the ranges of densities found in the three classes, particularly between IgA and IgM-containing cells. The 
Patients with Villous Atrophy

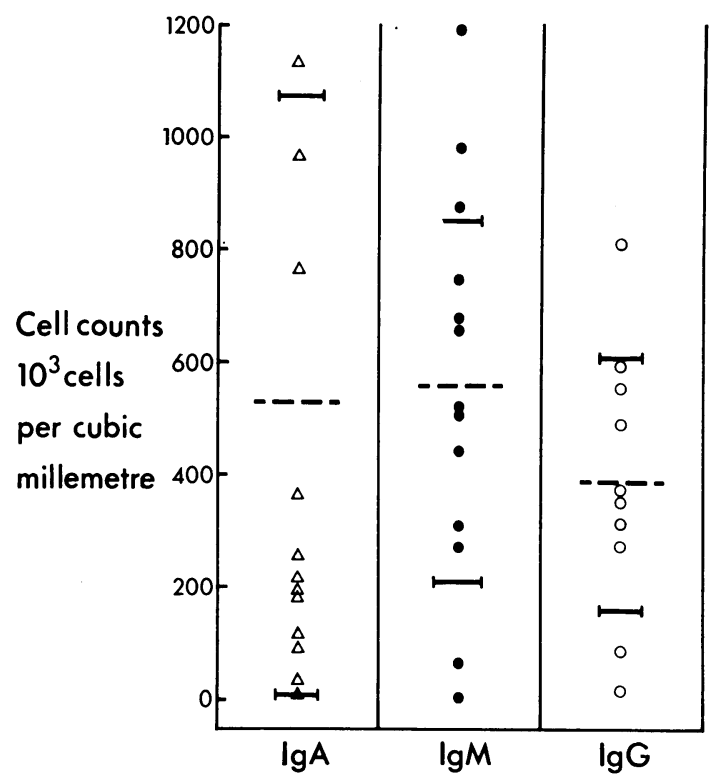

Fig. 2 Distribution of cell counts in patients with villous atrophy. No significant differences between mean densities. IgA-containing cells significantly lower than in the control group $(\mathrm{P}<0.01)$.

differences between the mean densities of the three types were all highly significant $(\operatorname{IgA} / \operatorname{IgM}: \mathrm{P}<0.001$; IgA/IgG: $P<0.001 ;$ IgM/IgG: $P<0.002$ ).

The fluorescence obtained in the sections from patients whose jejunum showed subtotal villous atrophy showed several differences from that seen in the group with normal histology.

Most of the immunoglobulin-containing cells in the lamina propria in this group did not show the same morphological characteristics as seen in the control group, and did not resemble plasma cells but appeared to correspond to lymphocytes, with a centrally located nucleus surrounded by a small rim of fluorescent cytoplasm. In three of the six patients the predominant immunoglobulin class contained in the mononuclear cells was IgA, but in the remaining three patients there was a decrease in the numbers of IgA cells compared to those of IgM and IgG. The population densities in the patients with subtotal villous atrophy are shown in Figure 2. There was no significant difference between the three populations of immunoglobulincontaining cells in this group, but the mean density of IgA-containing cells was significantly lower than the mean density of IgA-containing cells in the group with normal histology $(P=<0.01)$.

Correlations between random serum levels of the three immunoglobulin-containing cells in jejunal mucosa were performed on seven patients. There was a significant positive correlation for IgM $(P=<0.05)$.

There was no obvious clinical difference between patients with reduced numbers of IgA cells compared to those with normal numbers.

\section{Discussion}

The results of population densities of immunoglobulin-containing cells in the lamina propria of patients with normal histology are in agreement with all previous immunohistochemical studies showing that there is a predominance of IgA-containing cells throughout the gastrointestinal tract (Crabbé et al, 1965; Rubin et al, 1965; Crabbé and Heremans, 1966; Gelzayd, Kraft, Fitch, and Kirsner, 1967; Eidelman and Davis, 1968; Odgers and Wangel, 1968). However, the predominance of IgA-containing cells was not as marked; the approximate ratio of IgA/IgM/IgG cells was 3:2:1 respectively, compared with the ratio of 10:6:1 found by Crabbe $e t$ al. Also, the population densities of all cell types were much higher than those found by Crabbé et al (1965), and these differences in densities could either be related to differences in interpretation of fluorescence and the fact that the more sensitive indirect technique was used in this study or differences between the types of patient studied in this series compared with those studied by those workers.

Although their jejunal biopsies were normal the patients in this study were undergoing investigation of gastrointestinal symptoms, and it is possible that changes in the numbers and relative proportions of the immunoglobulin-containing cells may have occurred without affecting the gross histology of the small bowel.

The patient with coeliac disease whose biopsy had become normal after 10 years of treatment had the normal predominance of IgA-containing cells.

The results in patients with subtotal villous atrophy show that while some patients had the same predominance of IgA-containing cells in approximately the relative proportions as found in the group with normal histology, others had a decrease in the number of IgA cells so that the predominant cell type was IgM.

Rubin et al (1965) studied nine patients with coeliac disease and five control patients and found that the predominant cell type in all cases was IgA. However, their observations were not quantitated and changes in relative proportions of the cell types could have been missed. Also only two of the coeliac patients were untreated at the time of biopsy; and the remainder had shown histological remission of the villous atrophy to some degree. 
Søltoft (1970) studied 10 patients with coeliac disease both untreated and treated with a gluten-free diet but, regardless of treatment, all biopsy specimens had shown subtotal villous atrophy. IgA-containing cells remained predominant but there was a significant increase in the densities of IgM and IgG-containing cells and no differences were found between treated and untreated patients.

Douglas et al (1970) studied 13 patients with coeliac disease and demonstrated a reduction in the densities of IgA-containing cells, although in the majority IgA remained the predominant cell type. In both untreated and treated cases there was an increase in densities of IgM-containing cells, which occasionally even exceeded those containing IgA, and there was no increase in cells containing IgG. This increase in IgM cells was not seen in rectal biopsies or in bone marrow specimens, and was present even in patients whose serum IgM levels were subnormal. The IgM content of jejunal juice was also found to be increased in untreated coeliac patients.

This study supports these findings that there is a relative increase in the proportion of IgM and IgG cells in the lamina propria of patients with the coeliac syndrome, although this was due to a reduction in the numbers of IgA-containing cells rather than to a specific increase in those containing IgM. Relative reductions in the density of IgAcontaining cells in the bowel have been described in other conditions, such as ulcerative colitis (Gelzayd et al, 1967), ataxia telangiectasia (Eidelman and Davis, 1968), and pernicious anaemia (Odgers and Wangel, 1968).

Quantitation of immunofluorescence is subject to many errors whatever technique is used, but subjective bias and observer variation in the interpretation of specific fluorescence are probably the major sources of error. It is likely that some of the differences found between workers are due to their different interpretations of specific fluorescence. Also, a satisfactory definition of coeliac disease is not possible in the present state of knowledge, and the use of the term 'coeliac syndrome' for all patients with villous atrophy regardless of other clinical findings has been advocated (Hindle and Creamer, 1965). It is probable that this histological change results from several pathological mechanisms, which may not affect the proportions of immunoglobulincontaining cells in the lamina propria uniformly.

The explanation and significance of these changes in the pattern of immunoglobulin-containing cells in gastrointestinal disease is not clear. It is likely that some patients, such as those with selective IgA deficiency and those with ataxia telangiectasia, have a primary defect in the synthesis of serum and secretory $\operatorname{IgA}$, and the increase in the numbers of IgM and IgG cells in the gastrointestinal mucosa could be regarded as a compensatory mechanism. Lymph node histology in patients with selective IgA deficiency has demonstrated pronounced hyperplasia of paracortical lymphoid elements in contrast to less active germinal centres, suggesting an attempt by the cellular defences to compensate for deficient humoral defences (Hobbs, 1968). However, the majority of coeliac patients are able to synthesize IgA (Hobbs and Hepner, 1968; Asquith, Thompson, and Cooke, 1969), and a reduction in the numbers of IgA cells in some of these cases, with increased numbers of IgM and IgG cells, is likely to be a secondary phenomenon. The changes in immunocyte pattern appear to be localized to the affected part of the bowel and probably revert to the normal pattern in patients who have responded to the exclusion of gluten from the diet.

A greater proportion of the immunocytes morphologically resemble lymphocytes rather than plasma cells and could represent cells involved in an immune reaction within the mucosa, possibly derived from other lymphoid sources and containing immunoglobulin classes which are more effective against the antigens involved.

A kinetic study of immunocytes within the gastrointestinal tract may help to resolve such a hypothesis.

This work forms part of an M.D. thesis, London University, 1970.

I should like to thank Professor J. Anderson who provided facilities for this study. I am grateful to Dr D. E. H. Tee for the use of facilities in his department and for his valued advice and interest. I should also like to thank the physicians at King's College Hospital for permission to study their patients, the Department of Morbid Anatomy for the use of their cryostat, Mr K. C. McNamee of Gillett and Sibert Ltd for advice on fluorescent photomicroscopy, and Mrs M. Cooper for assistance with the figures.

\section{References}

Adinolfi, M., Glynn, A. A., Lindsay, M., and Milne, C. M. (1966). Serological properties of gamma $\mathbf{A}$ antibodies to $\mathbf{E}$. Coli. present in human colostrum. Immunology, 10, 517-526.

Asquith, P. Thompson, R. A., and Cooke, W. T. (1969). Serum immunoglobulins in adult coeliac disease. Lancet, 2, 129-131.

Bachmann, R. (1965). Studies on the serum gamma A-globulin level III. The frequency of A-gamma A-globulinaemia. Scand. J. clin. Lab. Invest., 17, 316-320.

Claman, H. N., Hartley, T. F., and Merrill, D. (1966). Hypogammaglobulinemia, primary and secondary; immunoglobulin levels. (YG, YA, YM) in 125 patients. J. Allergy, 38, 215-225.

Crabbé, P. A., Carbonara, A. O., and Heremans, J. F. (1965). The normal human intestinal mucosa as a major source of plasma cells containing gamma A immunoglobulin. Lab. Invest., 14, 235-248. 
Crabbe, P. A., and Heremans, J. F. (1966). The distribution of immunoglobulin-containing cells along the human gastrointestinal tract. Gastroenterology, 51, 305-316.

Crabbe, P. A., and Heremans, J. F. (1967). Selective IgA deficiency with steatorrhoea, a new syndrome. Amer. J. Med., 42, 319-326

Douglas, A. P., Crabbe, P. A., and Hobbs, J. R. (1970). Immunochemical studies of the serum, intestinal secretions and intestinal mucosa of patients with adult celiac disease and other forms of the coeliac syndrome. Gastroenterology, 59, 414-425.

Eidelman, S. and Davis, S. D. (1968). Immunoglobulin content of intestinal mucosal plasma cells in ataxia telangiectasia. Lancet, 1, 884-886.

Eidelman, S., Starkey, D. D., Lagunoff, D., and Rubin, C. E. (1966). The relationship between intestinal plasma cells and serum immunoglobulin A (IgA) in man. J. clin. Invest., 45, 1003-1004.

Fahey, J. L, , and McKelvey, E. M. (1965). Quantitative determination of serum immunoglobulins in antibody-agar plates. J.Immunol., 94, 84-90.

Gelzayd, E. A., Kraft, S. C., Fitch, F. W., and Kirsner, J. B. (1967). The distribution of immunoglobulins in the rectal mucosa in ulcerative colitis. Gastroenterology, 52, 1087.

Gugler, E., and von Muralt, G. (1959). Uber immunoelektrophoretische Untersuchungen an Frauenmilchproteinen. Schweiz. med. Wschr., 89, 925-929.

Hanson, L. A. (1960). The serological relationship between human milk and blood plasma. Int. Arch. Allergy, 17, 45-69.

Hindle, W., and Creamer, B. (1965). Significance of a flat small intestinal mucosa. Brit. med. J., 2, 455-458.

Hobbs, J. R. (1968). Immune imbalance in dysgammaglobulinaemia type iv. Lancet, 1, 110-114.

Hobbs, J. R., and Hepner, G. W. (1968). Deficiency of gamma M globulin in coeliac disease. Lancet, 1, 217-220.
Josephson, A. S., and Lockwood, D. W. (1964). Immunoelectrophoretic studies of the protein components of normal tears J. Immunol., 93, 532-539.

Mancini, G., Vaerman, J. P., Carbonara, A. O., and Heremans, J. F. (1964). A single radial diffusion method for the immunological quantitation of proteins. Protides biol. Fluids, 11, 370-373.

Masson, P. L., Heremans, J. F., and Prignot, J. (1965). Studies on the proteins of human bronchial secretions. Biochim. biophys. Acta (Amst.), 111, 466-478.

Nairn, R. C. (1964). Fluorescent Protein Tracing, 2nd ed., p. 110.

Odgers, R. J., and Wangel, A. G. (1968). Abnormalities in IgAcontaining mononuclear cells in the gastric lesion of pernicious anaemia. Lancet, 2, 846-849.

Rubin, W., Fauci, A. S., Sleisenger, M. H., and Jeffries, G. H. (1965). Immunofluorescent studies in adult celiac disease. J. clin. Invest., 44, 475-485.

Seltoft, J. (1970). Immunoglobulin-containing cells in non-tropical sprue. Clin. exp. Immunol., 6, 413-420.

Tokumaro, T. (1966). A possible role of gamma A immunoglobulin in herpes simplex virus infection in man. J. Immunol., 97, 248-259.

Tomasi, T. B., Jr., (1968). Human immunoglobulin A. New Engl. J. Med., 279, 1327-1330.

Tomasi, T. B., Jr., Tan, E. M., Solomon, A., and Prendergast, R. A. (1965). Characteristics of an immune system common to certain external secretions. J. exp. Med., 121, 101-124.

Tomasi, T. B., Jr., and Zigelbaum, S. (1963). The selective occurrence of gamma A globulins in certain body fluids. J. clin. Invest., 42, 1552-1560.

West, C. D., Hong, R., and Holland, N. H. (1962). Immunoglobulin levels from the newborn period to adulthood and in immunoglobulin deficiency states. J. clin. Invest., 41, 2054-2064. 